ACTA MYCOLOGICA

Vol. 41 (2): 313-318

2006
Dedicated to Professor Alina Skirgietto

on the occasion of her ninety fifth birthday

\title{
Persistence of ectomycorrhizas by Thelephora terrestris on outplanted Scots pine seedlings
}

\author{
DOROTA HILSZCZAŃSKA and ZBIGNIEW SIEROTA
}

Forest Research Institute

Bitwy Warszawskiej 1920 r. nr 3, PL 00973 Warszawa

D.Hilszczanska@ibles.waw.pl, Z.Sierota@ibles.waw.pl

Hilszczańska D., Sie rota Z.: Persistence of ectomycorrhizas by Thelephora terrestris on outplanted Scots pine seedlings. Acta Mycol. 41 (2): 313 318, 2006.

Thelephora terrestris (Erhr.) Fr. is a very common ectomycorrhizal symbiont (ECM) in conifer trees, however the role of this ubiquitous fungus in nurseries and Scots pine plantations is still unknown. It is described as tolerant of high nitrogen availability and therefore was taken into consideration as an important ECM partner of seedlings, particularly after replanting on post agricultural land. In laboratory the seedlings of Scots pine (Pinus sylvestris L.) were inoculated with $T$. terrestris (Tt/IBL/2) or not inoculated (control) and grown in containers in two different regimes of nitrogen fertilization $\left(4 \mathrm{~g} \mathrm{~N} \mathrm{x} \mathrm{kg}^{1}\right.$ and $\left.6 \mathrm{~g} \mathrm{~N} \mathrm{x} \mathrm{kg}^{1}\right)$. Next year these seedlings were outplanted in post agricultural land and 6 months later, the number and identity of some mycorrhizas were studied. It was found, that mycorrhizal abundance was higher in the inoculated treatments than in non inoculated ones. PCR RFLP analysis confirmed share of two different isolates of Thelephora engaged in mycorrhizal symbiosis. Part of mycorrhizas had the same pattern of RFLP as the isolate used to inoculation. Similar results were obtained in second year of experimental study in the field what confirmed the persistence of artificially introduced $T$. terrestris in post agricultural soil as an important component of the ECM community.

Key words: Thelephora terrestris, Scots pine seedlings, inoculation, ectomycorrhiza, post agricultural land, PCR, RFLP

\section{INTRODUCTION}

The root systems of most forest trees, including pines, form ectomycorrhizas (ECM) with various fungi. ECM colonization rate and species composition play an important role in the stability of forest ecosystems (Has elwandter, Bowe n 1996), especially on disturbed soils (Mullin s et al. 1989). Successful afforestation requires the early capture of site resources by tree seedlings. Early growth assures space, a continuing resource supply and vigour to resist pests, pathogens and climatic stress (Perry et al. 1987). 
In order to improve adaptation of pine seedlings destined to non-forest soils the artificial inoculation has been successfully used (Berry, Marx 1978; Castellano 1996). According to the National Afforestation Programme estimated area of abandoned lands that should be afforested is about 1.5 millions ha (Grzywacz 2000). Most frequent morphotypes identified on such sites were Pisolithus tinctorius, Scleroderma citrinum, Thelephora terrestris, Suillus sp., Tuber sp., Tomentella sp. (D a n ielson 1991; Hilszczańska 2002). The natural variability makes it necessary to develop selection strategies for ECM fungi as inocula in forest nurseries. The majority of screening programmes search for isolates that increase nutrient uptake and plant growth. Recent years have seen an increased awareness of the additional benefits of a fungal partner in the root system. Hence, different criteria may be used to select inoculant mycorrhizal fungi unrelated to ability to increase growth rates or nutrient uptake (Dodd, Thoms on 1994). Bowen (1994) claims that fungi used as inocula should be related and appropriate to soil conditions such as humidity, texture, chemistry and nutrient availability. T. terrestis is a very common ectomycorrhizal symbiont and occurs on a wide variety of soils, including non-fertilised and highly fertilised, mineral or peaty soils, and in dry or wet conditions (Colpa ert 1999).

In presented study T. terrestris mycelium was used as inoculum for seedlings which were grown in control conditions in the laboratory. After inoculation two different nutrient supply were applied and next year later, 1-year old seedlings were outplanted on post-agricultural land. The aim of this work was to estimate the presence and share of T. terrestris mycorrhizas.

\section{MATERIALS AND METHODS}

For the laboratory study, the selected seeds of $P$. sylvestris were taken from Gene Bank in Kostrzyca, Poland and surface sterilised for 15 min. in $30 \%$ hydrogen peroxide. The seeds were sown to containers (Root Trainer, v $123 \mathrm{~cm}^{3}$ ) containing a previously autoclaved mixture of peat moss and vermiculite $(2: 1, \mathrm{v} / \mathrm{v})$. Nitrogen was the growth limiting element and consisted of $47.4 \%$ ammonium and 52, $6 \%$ nitrate. In one variant used, each plant was fertilized with $0,2 \mathrm{~g} \mathrm{~N}$ per plant, that gives $4 \mathrm{~g} \mathrm{~N} \mathrm{x}$ $\mathrm{kg}^{-1}$ of soil (low $\mathrm{N}$ ), and in second variant each plant was fertilized with $0,3 \mathrm{~g} \mathrm{~N}$ per $\mathrm{x} \mathrm{kg}^{-1}$ of soil plant $-6 \mathrm{~g} \mathrm{x} \mathrm{kg}^{-1}$ of soil (high $\mathrm{N}$ ). The $\mathrm{pH}_{\mathrm{KCl}}$ of soil was 4.1 The experiment was carried out during 1 year in a growth chamber with a day/night rhythm of $18 / 6 \mathrm{~h}$ and $22 / 15^{\circ} \mathrm{C}$ at least $70 \%$ relative air humidity. Inoculation of seedlings was done 28 days after sowing, with blended mycelium of Thelephora terrestris (Erhr.) Fr. (Tt/IBL/2, isolated from the fruitbody); each seedling received $5 \mathrm{ml}$ of mycelium suspended in deionised water ( $0.025 \mathrm{~g}$ mycelium per plant). Seedlings were grown in four treatments: 1- high $\mathrm{N}$ and inoculation, 2- low $\mathrm{N}$ and inoculation, 3- high $\mathrm{N}$ without inoculation, 4- low $\mathrm{N}$ without inoculation (Hilszczańska, Sierota 2006). Six months after inoculation, 15 seedlings from each treatment were selected randomly for determination of the degree of mycorrhizal colonisation. Next year, at the beginning of spring 2004 seedlings were outplanted on post agricultural land in Jabłonna Forest District. Within the area, mean annual precipitation is about 522.8 $\mathrm{mm}$ and average temperature during the growth season is $c a .8 .4^{\circ} \mathrm{C}$. The land had been abandoned for over 1-year prior to our study. The site is characterised by sandy soil, corresponding to vaccinio-myrtilliosa forest type. Planting was carried out 
Table 1

Mean content of minerals in the soil $20 \mathrm{~cm}$ deep $\left(\mathrm{g} \mathrm{x} \mathrm{kg}^{1}\right)$ and $\mathrm{pH}$

\begin{tabular}{|c|c|c|c|c|c|c|c|c|}
\hline $\mathrm{C}$ & $\mathrm{N}$ & $\mathrm{Ca}$ & $\mathrm{Mg}$ & $\mathrm{K}$ & $\mathrm{P}$ & $\mathrm{S}$ & $\mathrm{Al}$ & $\mathrm{pH}_{\mathrm{KCL}}$ \\
\hline 8.3 & 0.85 & 1.17 & 0.67 & 0.75 & 0.63 & 0.10 & 5.55 & 4.48 \\
\hline
\end{tabular}

in the scheme of randomised block design with four treatments as previously. Soil samples (cores were taken to a depth of $20 \mathrm{~cm}$ at 5 different location) were collected in April 2004. Soil $\mathrm{pH}_{\mathrm{KCl}}$ and the basic nutrients were determined (Tab. 1).

After the first growing season (2004) and next after the second year (2005) samples of plants ( 15 plants from each treatment) were taken in order to assess the presence of T. terrestris mycorrhizas and the composition of the ECM communities. Prior to investigation, each root systems were excised from the stems and washed in tap water. Mycorrhizal tips were counted and morphotyped as described by Age re r (1987-1997), Ingle by et al. (1990) and Parla de et al. (1996).

The morphotypes which did not match any of those presented in cited material were classed as unidentified. In order to confirm that morphotyping was well done, 22 mycorrhizal tips from all treatments were taken to DNA analysis with PCR RFLP method, conducted in the Institute of Biology and Biochemistry. The fungal specific primer ITS1-F (Gardes, Bruns 1993) and universal primer ITS 4 (White et al. 1990) have been used for amplification by PCR. If only one DNA band was present per sample (confirming that all DNA came from one source only), the product was used for RFLP analysis. Digestions with the restriction enzymes Hinf I, Mbo I and Taq I were performed using 18 ul DNA from amplifications of mycorrhizal origin. Analysis of the restriction patterns was made on 2,4 agarose gels which were stained with ethidium bromide.

The variability of mycorrhizas was assessed by analysis of variance (ANOVA), significant differences of means were compared by LSD $(\mathrm{P}<0.05)$ (StatSoft, Inc. (2005). STATISTICA (data analysis software system, version 7,1. www.statsoft.com) 1998).

\section{RESULTS}

After the first season, irrespective of nitrogen amount, higher number of mycorrhizas possessed the inoculated seedlings than non-inoculated ones (Fig. 1A). At inoculated treatments number of mycorrhizas did not differ significantly between low $\mathrm{N}$ and high N: 659 and 728, respectively. At non-inoculated treatments the number of mycorrhizas was significantly lower; in low N - 489 and in high $\mathrm{N}-328$. The differences between inoculated and non-inoculated seedlings were also statistically significant.

After the first growing season, the mycorrhizas at inoculated treatment with high amount of $\mathrm{N}$ were mostly formed by $T$. terrestris (Tab. 2), while at treatment with low $\mathrm{N}$ mycorrhizas formed by Hebeloma sp. had the highest number. Moreover, the last mycorrhizas were dominant morphotype on non-inoculated seedlings, irrespec- 

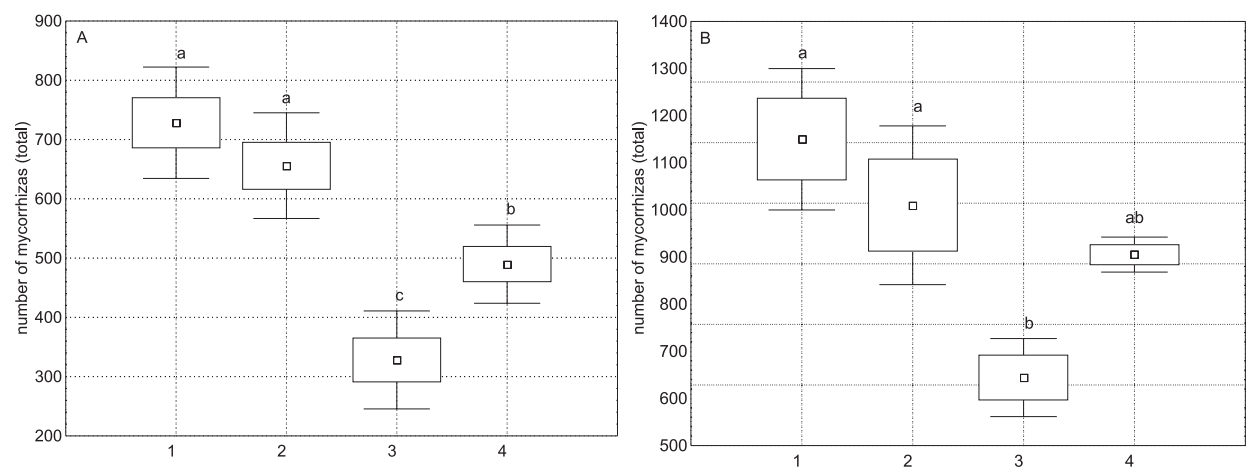

Fig. 1. Number of mycorrhizas on Scot pine seedlings: A first growing season, B the second growing season. Statistically significant differences between the treatments ( 1 high $\mathrm{N}$ and in oculation, 2 low $\mathrm{N}$ and inoculation, 3 high $\mathrm{N}$ without inoculation, 4 low $\mathrm{N}$ without inocula tion) are designated by different letters. Error bars indicate standard error of the mean.

tive of $\mathrm{N}$ level. At all treatments percentage of mycorrhizas formed by Amanita sp. varied from 5 to $10 \%$.

Mycorrhizas formed by Thelephora sp. at non-inoculated treatment belonged to a strain that we called as Thelephora II - indigenous in that soil. It has been confirmed by PCR RFLP analysis (Tab. 3). Thelephora I was the same strain that had been used to inoculation. Assessment of the accurate number of mycorrhizas formed by both strains was not possible due to lack of morphological differences. Among all

Table 2

Frequency of mycorrhizal morphotypes on root tips of Pinus sylvestris seedlings under different treatments in 2004 and 2005

\begin{tabular}{|l|c|c|c|c|c|c|c|c|}
\hline \multirow{3}{*}{ Morphotypes } & \multicolumn{4}{|c|}{ Year 2004 } & \multicolumn{4}{c|}{ Year 2005 } \\
\cline { 2 - 9 } & \multicolumn{2}{|c|}{ Inoculated } & Non inoculated & \multicolumn{2}{c|}{ Inoculated } & \multicolumn{2}{c|}{ Non inoculated } \\
\cline { 2 - 9 } & High N & Low N & High N & Low N & High N & Low N & High N & Low N \\
\hline $\begin{array}{l}\text { Amanita } \text { sp. } \\
\text { Hebeloma } \text { sp. }\end{array}$ & 10.0 & 5.0 & 4.0 & 8.0 & & & 10 & 5 \\
$\begin{array}{l}\text { Suillus sp. } \\
\text { Thelephora } \\
\text { terrestris } \\
\text { Unidentified }\end{array}$ & 75.0 & 60.0 & 80.0 & 75.0 & 10.0 & 25.0 & 5.0 & 25.0 \\
\hline & 5.0 & 5.0 & 10.0 & 15.0 & 60.0 & 70.0 & 50.0 & 5.0 \\
\hline
\end{tabular}

Table 3

Approximate restriction fragment sizes (bp) of the amplified fungal ITS region of T. terrestris mycorrhizas

\begin{tabular}{|l|c|c|c|c|}
\hline \multicolumn{1}{|c|}{ Fungus } & ITS & Hinf I & Mbo I & Tag I \\
\hline Thelephora terrestris (pure culture) & 680 & 315240103 & 36022560 & 295270 \\
\hline Thelephora (I) & 663 & 318242105 & 36522658 & 29727065 \\
\hline Thelephora (II) & 718 & 228208134115 & 24523615567 & 29522410898 \\
\hline
\end{tabular}


mycorrhizas analysed by PCR RFLP method, strain Thelephora I was found in $36 \%$ of samples and strain Thelephora II in $64 \%$ of samples.

After the second growing season, irrespective of inoculation or fertilization, all seedlings possessed higher number of mycorrhizas than after the first growing season. The highest number of mycorrhizas was observed at inoculated treatment with high amount of $\mathrm{N}$ and the lowest one at non- inoculated treatment with high amount of N (Fig. 1B). Mycorrhizas of T. terrestris were found on seedlings at all treatments, but the highest share was found at treatment inoculated with low N (Tab. 2). In mycorrhizal structure emerged mycorrhizas of Suillus sp. that had similar percentage at high level of $\mathrm{N}$ in case inoculated and non-inoculated treatments. The highest percentage of those mycorrhizas was noticed at non-inoculated treatment with high $\mathrm{N}$. According to PCR RFLP analysis (which was successful in case of 30 mycorrhizas) the percentage of mycorrhizas formed by Thelephora I was about $30 \%$, whereas by Thelephora II was $70 \%$.

\section{DISCUSSION}

After two growing seasons following plantation establishment, the Scots pine seedlings inoculated with $T$. terrestris showed significantly higher number of mycorrhizas than non-inoculated seedlings (Fig. 1A and B). The morphotypes of T. terrestris were also found on non-inoculated seedlings, it was clearly confirmed, that these ones were formed by indigenous strain of $T$. terrestris colonising only the limited part of roots, however. The other observed mycorrhizas were similar to those commonly observed in forest nurseries (Menkis et al. 2005).

The dominant mycorrhizas on non-inoculated seedlings and seedlings that were grown at low $\mathrm{N}$ fertilization belonged to Hebeloma sp. After second growing season the number of these mycorrhizas in root system was rather small. According to Guid ot et al. (2003) some fungi as $H$. cylindrosporum were replaced by others even after one growing season and do not necessarily contribute to next generation of mycorrhizas. Similar results described Menkis at al. (2005). The results indicate that i) the success of mycorrhizal inoculation in the field largely depends on fungal species, both used in mycorrhization and existing in the local soil, and ii) the ecological conditions of the soil will drive mycorrhizal colonisation at a given site (McAfee, Fortin 1985). This site was suitable for T. terrestris since after second season the mycorrhizas were the dominant morphotype. Even if inoculated strain was in small portion, compare to the indigenous one, it was still present. This might suggested that $T$. terrestris is a strong competitor or that can thrive in species-poor communities.

\section{REFERENCES}

Agerer R. 1987 1997. Colour Atlas of Ectomycorrhizae. Einhorn Verlag, Schwabisch Gmünd.

Berry C. R., Marx D. H. 1978. Survival and growth of pine hybrid seedlings with Pisolithus ectomycor rhizae on coil spoil in Alabama and Tennessee. J. Environ. Qual. 11: 709715.

Bowen G. D. 1994. The ecology of ectomycorrhiza formation and functioning. Plant and Soil 159: 61 67.

Castellano M. A. 1996. Outplanting performance of mycorrhizal inoculated seedlings. (In:) K. G. Mukerji (ed.). Concepts in mycorrhizal research. Handbook of vegetation science Kluwer, Dor drecht 19 (2): 223301. 
Colpaert J. V. 1999. Thelephora. (In:) J. W.G Cairney, S. M Cha mbers (eds). Ectomycorrhizal Fungi. Key Genera in Profile. Springer.

Danielson R. M. 1991. Temporal changes and effects of amendments on the occurrence of sheating (ecto )mycorrhizae of conifers growing in oil sands tailings and coal spoil. Agric. Ecosyst. Environ. 35: 261281.

Dodd J.C., Thomson B.D. 1994. The screening and selection of inoculant arbuscular mycorrhizal and ectomycorrhizal fungi. Plant and Soil 159: 149158.

Gardes M., Brun s T. 1993. ITS primers with enhanced specifity for basidiomycetes application to the identification of mycorrhizas and rusts. Mol. Ecol., 2:113 118.

Grzyw acz. A. 2000. Stan i potrzeby w zakresie mikoryzacji sadzonek drzew leśnych w Polsce na tle pro dukcji szkółkarskiej oraz zadań w zakresie zwiększenia lesistości kraju. (In:) M. Rudawska (ed.). Ektomikoryza, jej znaczenie i zastosowanie w leśnictwie, Instytut Dendrologii PAN, Kórnik.

Guidot A., Debaud J. C., Effosse A., Marmeisse R. 2003. Below ground distribution and per sistence of an ectomycorrhizal fungus. New Phytol. 161: 539547.

Ha s e lw a nd t e r K., B ow en G. D. 1996. Mycorrhizal relations in trees for agroforestry and land reha bilitation. For. Ecol. Manage. 81: 117.

Hilszczańska D. 2002. Mycorrhizal fungi in Scots pine cultures after seedlings out planting on post agricultural lands. Folia Forestalia Polonica, Series A Forestry 44: 97102.

Hilszczańska D., Sierota Z. 2006. The role of Thelephora terrestris fungus in mycorrhization on Scots pine (Pinus sylvestris L.) seedlings I. Laboratory study. Sylwan 1: 4047.

Ingle by K., Mas on P.A., Last F.T., Fleming L.V. 1990. Identification of ectomycorrhizas. ITE re search publication no.5. Institute of Terrestrial Ecology. London:HMSO.

McAfee B. J., Fortin J. A. 1985. Competitive interactions of ectomycorrhizal mycobionts under field conditions. Can. J. Bot. 64: 848852.

Men kis A. 2005. Root associated fungi of conifer seedlings and their role in afforestation of agricultural land. Swedish University of Agricultural Sciences, Doctoral Thesis 106, Uppsala.

Parlade J., Alvare z I. F., Pe r a J. 1996. Inoculation of containerized Pseudotsuga menziesii and Pinus pinaster seedlings with spores of five species of ectomycorrhizal fungi. Mycorrhiza 6: 237245.

Perry D. A., Molina R., Am ar a nthus M. P. 1987. Mycorrhizae, mycorrhizpspheres, and reforesta tion: current knowledge and research needs. Can. J. For. Res. 17:929 940.

White T. J., Bruns T., Lee S., Taylor J. 1990. Amplification and direct sequencing of fungal ribo somal RNA genes for phylogenetics. (In:) M. A. In n is, D. H. Ge fl and, J. Sninsky, T. J. White (eds). PCR Protocols. A Guide to Methods and Amplifications: 315 322. Academic Press.

\section{Trwałość ektomikoryz Thelephora terrestris u sadzonek sosny w uprawie}

\section{Streszczenie}

Sadzonki sosny zwyczajnej Pinus sylvestris L., mikoryzowane grzybnią Thelephora terrestris i nie mikoryzowane (kontrola) hodowano w laboratorium w dwóch wariantach nawożenia (4g $\mathrm{Nx} \mathrm{kg}{ }^{1}$ and $6 \mathrm{~g} \mathrm{Nx} \mathrm{kg}^{1}$ ) a po roku wysadzono na gruncie porolnym. W ciągu dwóch sezonów wegetacyjnych badano stan ilościowy i jakościowy mikoryz oraz określono tożsamość partnera grzybowego. Wyższą ogólną liczbą mikoryz charakteryzowały się sadzonki sztucznie miko ryzowane. Analiza DNA grzybowego przeprowadzona metodą PCR RFLP wykazała, że na badanych korzeniach mikoryzy T. terrestris tworzone były przez dwa izolaty Thelephora; izolat użyty do inokulacji siewek (Thelephora I) i izolat obecny w glebie (Thelephora II). Mikoryzy tworzone $\mathrm{z}$ udziałem inokulowanej grzybni obecne były na korzeniach jeszcze w dwa lata po wysadzeniu sadzonek na gruncie porolnym i stanowiły $30 \%$ udziału, podczas gdy mikoryzy autochtoniczne Thelephora II $70 \%$. 